\title{
Morphological, Anatomical, and Phytochemical Studies of Carlina acaulis L. Cypsela
}

\author{
Maciej Strzemski ${ }^{1, *(1)}$, Bartosz J. Płachno ${ }^{2, *}{ }^{\mathbb{C}}$, Barbara Mazurek ${ }^{3}{ }^{\oplus}$, Weronika Kozłowska ${ }^{4}(\mathbb{D}$, \\ Ireneusz Sowa ${ }^{1}{ }^{\circledR}$, Krzysztof Lustofin ${ }^{2}$, Daniel Załuski ${ }^{5}{ }^{\circledR}$, Lukasz Rydzik ${ }^{6}{ }^{\circledR}$, \\ Dariusz Szczepanek ${ }^{7}$, Jan Sawicki ${ }^{1}$ and Magdalena Wójciak ${ }^{1}$ \\ 1 Department of Analytical Chemistry, Medical University of Lublin, 20-093 Lublin, Poland; \\ i.sowa@umlub.pl (I.S.); 91chem91@gmail.com (J.S.); kosiorma@wp.pl (M.W.) \\ 2 Department of Plant Cytology and Embryology, Institute of Botany, Faculty of Biology, Jagiellonian \\ University in Kraków, 30-387 Krakow, Poland; krzysztof.lustofin@doctoral.uj.edu.pl \\ 3 Analytical Department, New Chemical Syntheses Institute, 24-110 Puławy, Poland; \\ barbara.mazurek@ins.lukasiewicz.gov.pl \\ 4 Department of Pharmaceutical Biology, Wroclaw Medical University, 50-556 Wroclaw, Poland; \\ weronika.kozlowska@umed.wroc.pl \\ 5 Department of Pharmaceutical Botany and Pharmacognosy, Ludwik Rydygier Collegium Medicum, \\ Nicolaus Copernicus University, 85-094 Bydgoszcz, Poland; daniel_zaluski@onet.eu \\ 6 Faculty of Physical Education and Sport, Institute of Sport, University of Physical Education in Krakow, \\ 31-541 Kraków, Poland; lukasz.gne@op.pl \\ 7 Chair and Department of Neurosurgery and Paediatric Neurosurgery, Medical University of Lublin, \\ 20-090 Lublin, Poland; dariusz.szczepanek@umlub.pl \\ * Correspondence: maciej.strzemski@poczta.onet.pl (M.S.); bartosz.plachno@uj.edu.pl (B.J.P.); \\ Tel.: +48-81-448-7180 (M.S.); +48-12-664-60-39 (B.J.P.)
}

Received: 4 November 2020; Accepted: 2 December 2020; Published: 3 December 2020

\begin{abstract}
Carlina acaulis L. has a long tradition of use in folk medicine. The chemical composition of the roots and green parts of the plant is quite well known. There is the lowest amount of data on the cypsela (fruit) of this plant. In this study, the microscopic structures and the chemical composition of the cypsela were investigated. Preliminary cytochemical studies of the structure of the Carlina acaulis L. cypsela showed the presence of substantial amounts of protein and lipophilic substances. The chemical composition of the cypsela was investigated using spectrophotometry, gas chromatography with mass spectrometry, and high-performance liquid chromatography with spectrophotometric and fluorescence detection. The cypsela has been shown to be a rich source of macro- and microelements, vegetable oil (25\%), $\alpha$-tocopherol (approx. $2 \mathrm{~g} / \mathrm{kg}$ of oil), protein (approx. 36\% seed weight), and chlorogenic acids (approx. $22 \mathrm{~g} / \mathrm{kg}$ seed weight). It also contains a complex set of volatile compounds. The $C$. acaulis cypsela is, therefore, a valuable source of nutrients and bioactive substances.
\end{abstract}

Keywords: essential amino acid; unsaturated fatty acids; chlorogenic acids; tocopherols; mineral composition

\section{Introduction}

Seeds of many plant species are a valuable source of various nutrients, e.g., oil, protein, carbohydrates, and biologically active secondary metabolites. Seed oils are rich in unsaturated fatty acids [1], which are highly important for human health, as they prevent the development of many diseases such as cancer, cardiovascular diseases, and diabetes. They are also essential for the proper development of the fetus and cognitive functions [2]. Tocols (tocopherols and tocotrienols) present in 
oils, referred to as vitamin E, play important roles in the human organism, preventing oxidation of the components of the cell membrane, polyunsaturated fatty acids, and low-density lipoproteins [3]. Additionally, seeds have a diversified mineral composition with high content of various micro- and macroelements [4]. Plant seeds are, therefore, a valuable source of phytochemicals with great medicinal and dietary importance. They are also important in animal nutrition. Moreover, seed oils are a desirable component of various cosmetic preparations $[5,6]$. This prompts research on plant seeds that have not been studied so far.

Carlina acaulis L. (Figure 1A) is a monocarpic perennial plant from the Asteraceae family occurring in South and Central Europe. Carlina root has been used in medicine since ancient times mainly for treatment of skin diseases, in treatment of dental and gastrointestinal tract diseases, and as an anthelmintic and diuretic agent. Some reports also indicate the therapeutic potential of aerial parts in skin diseases $[7,8]$. The chemical composition of the roots and green parts of C. acaulis is quite well known and established mostly by chromatographic techniques: high-performance thin-layer chromatography (HPTLC), high-performance liquid chromatography (HPLC), and gas chromatography (GC). For example, carlina oxide and inulin were found as the main phytochemicals in roots [9], and leaves were shown to contain flavonoids [10], chlorogenic acids, and considerable amounts of oleanolic and ursolic acids [11,12]. In contrast, there are scarce reports on the phytochemistry of seeds. They are limited to one publication from 1969 [13], in which the fatty acid profile of C. acaulis fruit oil was examined and only five fatty acids were identified and quantified.

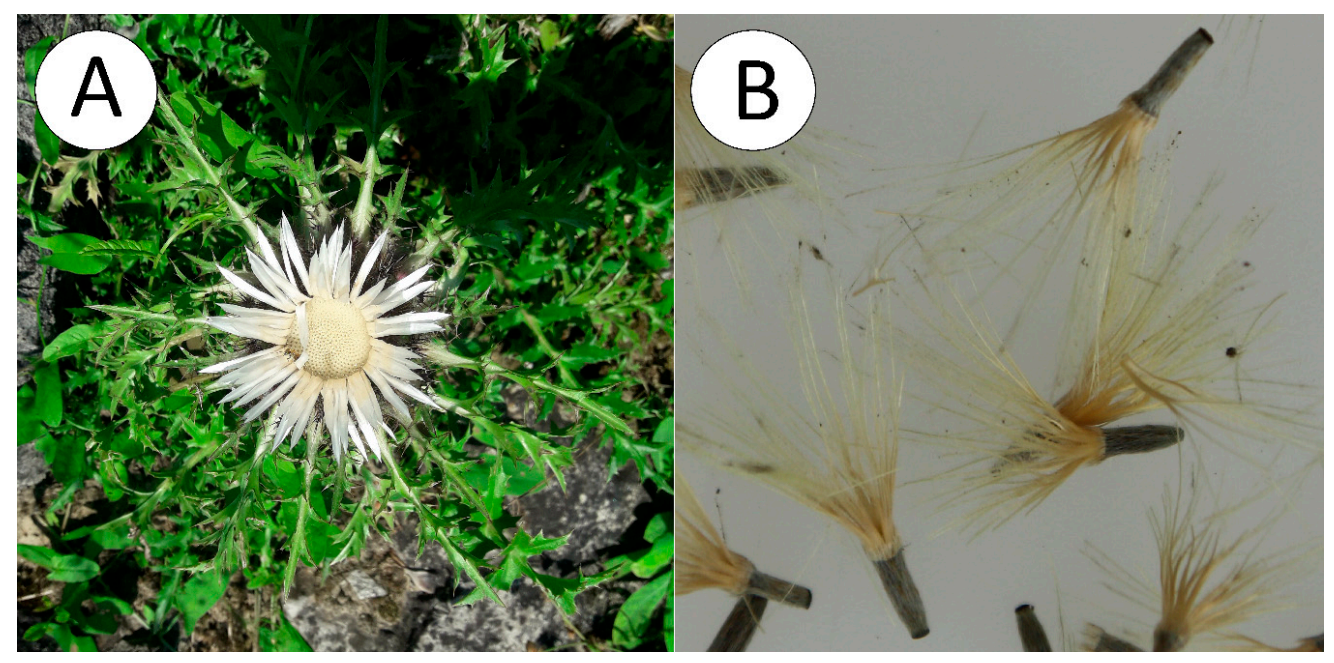

Figure 1. (A). Flowering plant Carlina acaulis L., (B). Mature cypselae.

The seeds of Asteraceae plants are botanically their fruits and are referred to as cypselae. The cypsela is a complex, indehiscent, dry, unilocular fruit with a single seed not adnate to the pericarp and derived from an inferior ovary [14]. The data in the literature indicate that cypselae of some Asteraceae species are rich in protein and oil (e.g., [15]), and immatured cypselae of some genera (Taraxacum, Hieracium, Pilosella) contain large amounts of polysaccharides [16-18].

The aim of our study was to investigate the morphological and anatomical structure of $C$. acaulis cypselae using such imaging techniques as light and scanning electron microscopy (SEM). Moreover, the chemical composition of cypselae was evaluated taking into account the content of primary and secondary metabolites as well as the mineral profile. The following techniques have been used: gas chromatography with mass spectrometry (GC-MS), HPLC with photodiode (DAD) and fluorescence (FLD) detection, ultra-performance liquid chromatography with fluorescence detection (UPLC-FLD), inductively coupled plasma-optical emission spectrometry (ICP-OES), attenuated total reflectance infrared spectroscopy (ATR-IR), and UV-VIS spectrophotometry. To our knowledge, this is the first study on the cell structure and chemical composition of the C. acaulis cypsela. 


\section{Results and Discussion}

\subsection{Macro- and Microscopy Analysis}

C. acaulis cypselae (Figure 1B) are oblong, with 4-6 mm length and approx. $1 \mathrm{~mm}$ width. They are brown and are covered with silver hairs. They possess pappus with a length from 15 to $17 \mathrm{~mm}$, which consists of 5-8 hairs stuck together at the base. The thousand seed weight without the calyx fluff is $3.60 \pm 0.08 \mathrm{~g}$.

As shown by the microscopic imaging, the mature cypsela (Figure 2A) was mostly occupied by a large embryo (Figure 2B-D), which was covered by the pericarp overlain by the testa (Figure 2E). In transverse section, the shape of the cypsela was mainly elliptical (Figure 2B). The embryo cells (cells of both the epidermis and parenchyma) were filled with storage materials in the form of approximately globular structures (Figure 2F).
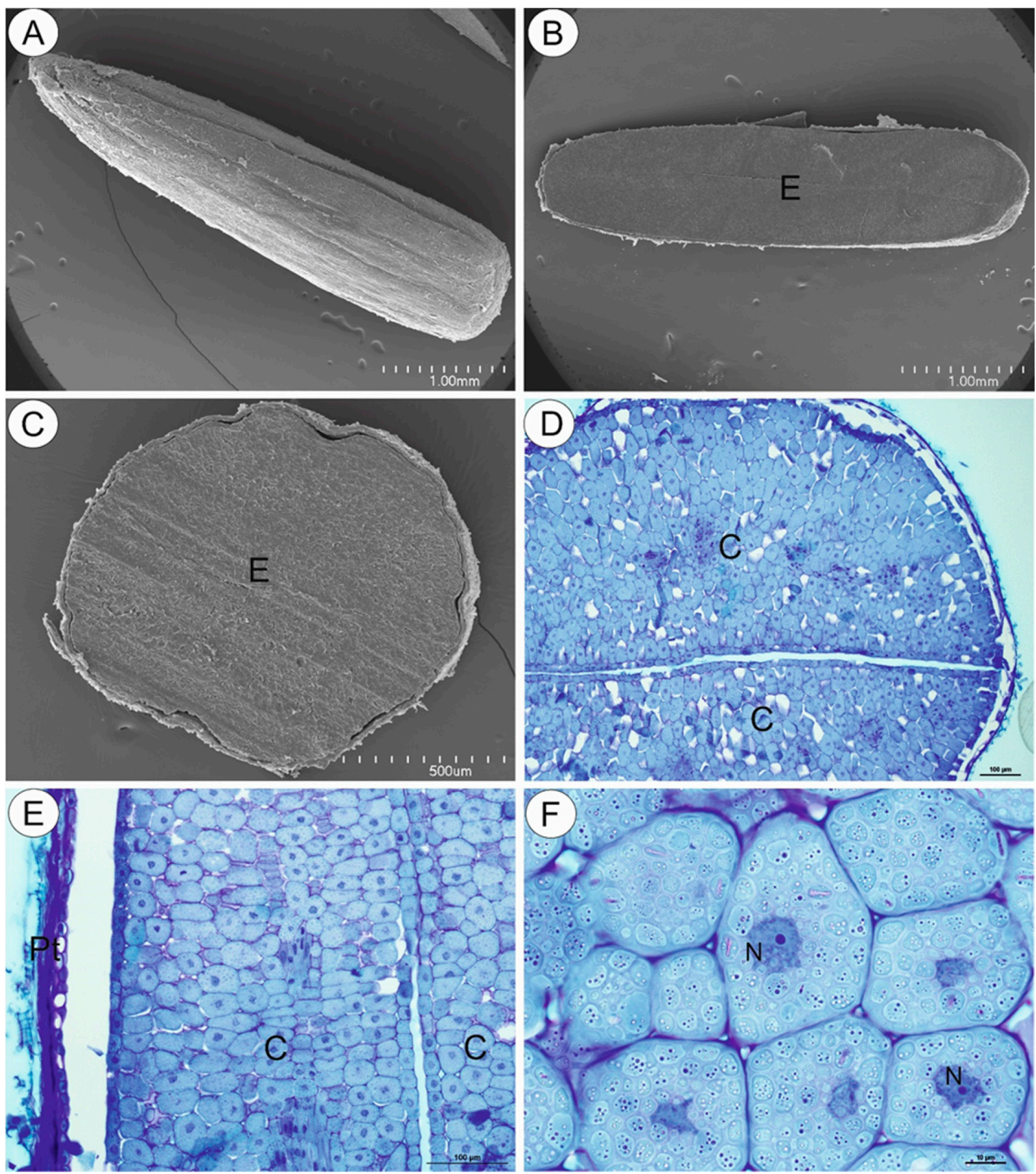

Figure 2. Structure of the Carlina acaulis cypsela. (A). Morphology of the cypsela in scanning electron microscopy (SEM), bar $1 \mathrm{~mm}$. (B). Transverse section of the cypsela; embryo (E) in SEM, bar $1 \mathrm{~mm}$. (C). Cross section through the cypsela; embryo (E) in SEM, bar $500 \mu \mathrm{m}$. (D). A part of cross section through the cypsela; two cotyledons are well visible (C), bar $100 \mu \mathrm{m}$. (E). A part of transverse section through the cypsela; pericarp and testa (Pt), cotyledon (C), bar $100 \mu \mathrm{m}$. (F). Parenchyma cells of the cotyledon; note the cytoplasm filled with storage material, nucleus $(\mathrm{N})$, bar $10 \mu \mathrm{m}$. 
The NBB staining revealed that these structures were protein bodies (Figure 3A,B). The results of PAS reaction confirmed the presence of carbohydrates located mostly in the cell walls, and no starch grains were detected in the embryo cells (Figure 3C). The Sudan Black B staining gave a negative result, which indicated the absence of lipid bodies (Figure 3D). In the plant material treated with the osmium tetroxide solution (Figure 4A,B), some embryo cells had osmiophilic granules in the cytoplasm, suggesting their lipid character.
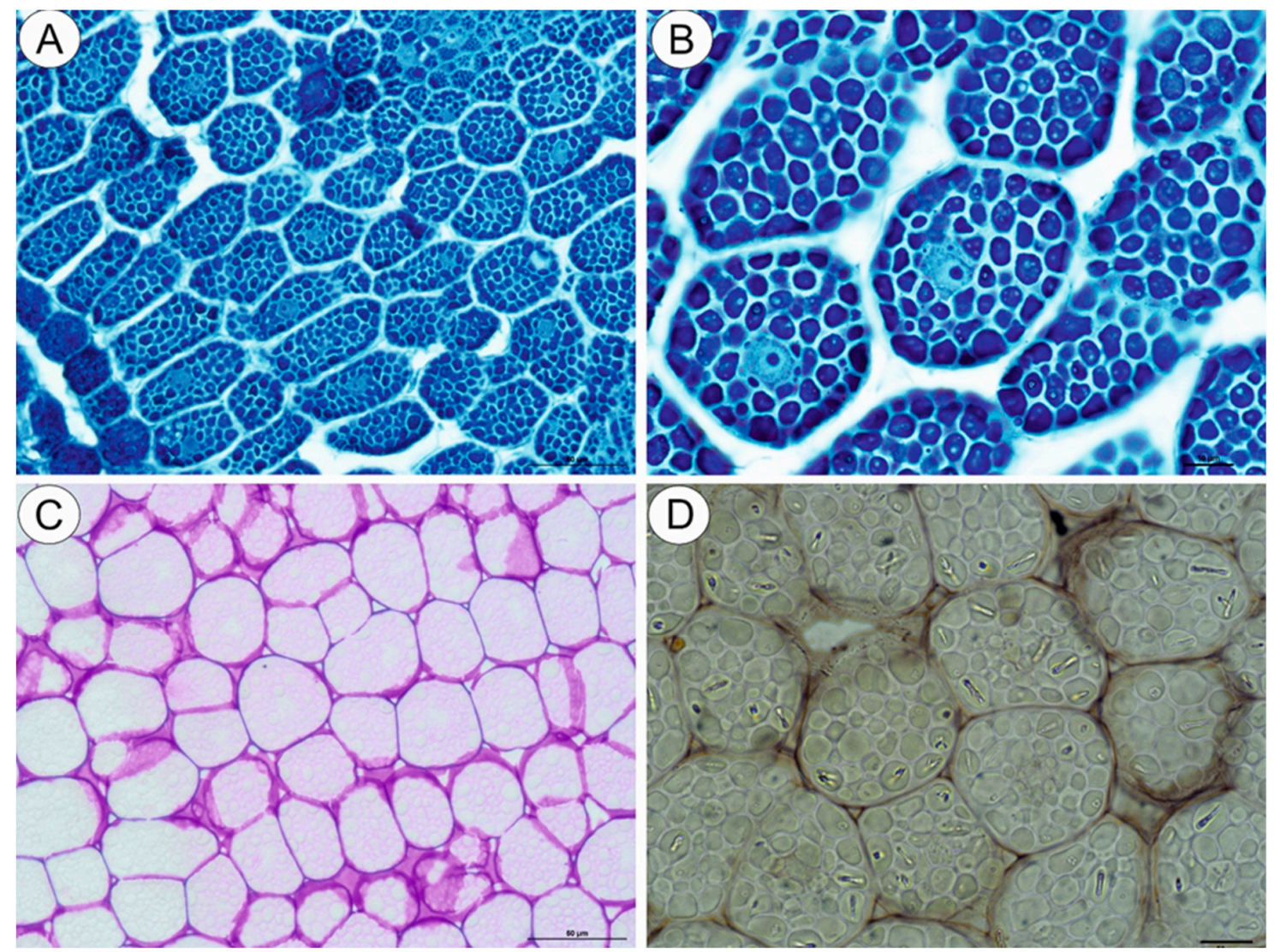

Figure 3. Cytochemistry of Carlina acaulis embryo cells. (A,B). NBB staining, bar $50 \mu \mathrm{m}$ and bar $10 \mu \mathrm{m}$. (C). PAS reaction' note the presence of polysaccharides only in the cell walls, bar $50 \mu \mathrm{m}$. (D). Sudan Black B staining, bar $10 \mu \mathrm{m}$.

We did not detect starch grains in the embryo cells of Carlina acaulis; however, as shown by Jacobsen [19], the occurrence of starch grains in cotyledons depends on the species. In other species from the Asteraceae family starch was not found as storage material in embryos, e.g., in sunflower cultivars [15] and Trichocline catharinensis [20].

Protein reserves are an important storage of nitrogenous compounds, which are essential during germination and development of young seedlings. They are a common seed storage material [21]. In plants, proteins are selectively accumulated and packaged in specialized vacuoles referred to as protein bodies [22,23]. As reported by Boesewinkel and Bouman [21], protein bodies are located in the entire embryo or endosperm or they are restricted to a specialized layer. Here, we show that protein bodies in Carlina acaulis are found in the entire embryo and are dominant organelles in embryo cells.

Studies have reported the presence of protein bodies in the embryo cells in the other members of the Asteraceae family as well $[15,20]$. 


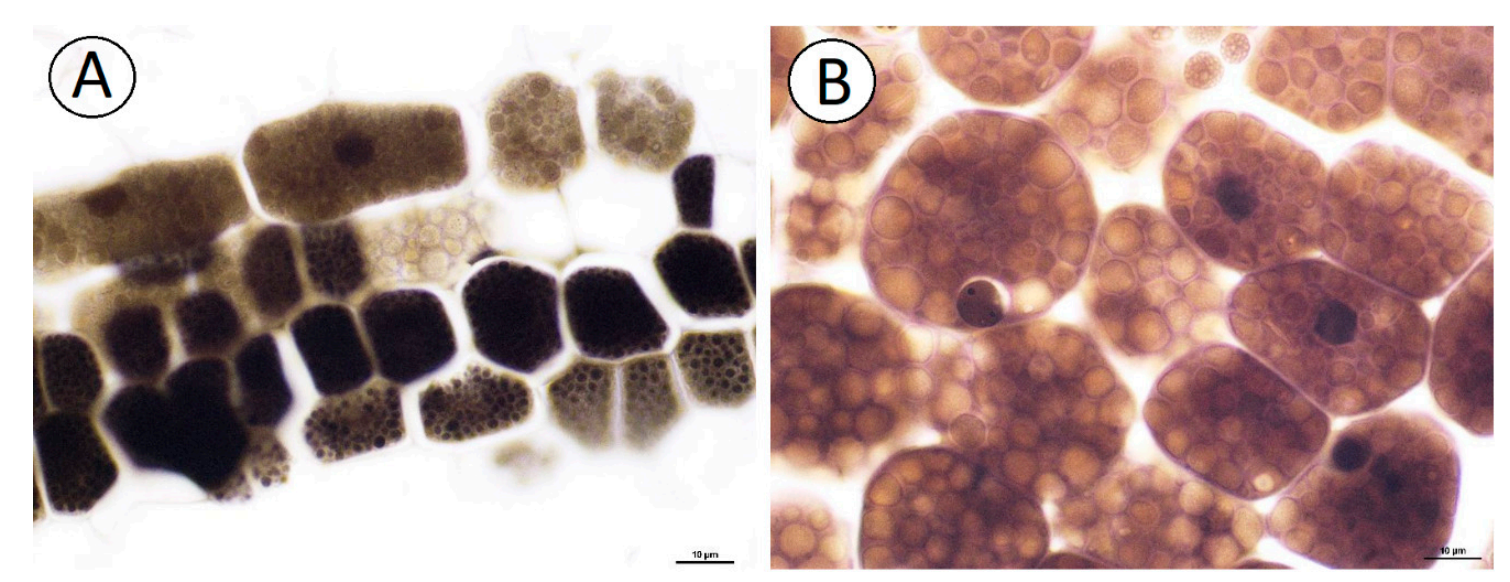

Figure 4. Cytochemistry of Carlina acaulis embryo cells. (A). Material treated with the osmium tetroxide solution; some embryo cells have osmiophilic granules in the cytoplasm, bar $10 \mu \mathrm{m}$. (B). Material treated with the osmium tetroxide solution. Embryo cells; note the cytoplasm filled with protein bodies that are not osmiophilic, bar $10 \mu \mathrm{m}$.

Using chemical methods, we showed that Carlina acaulis cypselae contained oils (fatty acids); however, Sudan Black B staining gave a negative result, which indicated the absence of lipid bodies. In contrast, lipid bodies were a common cell feature of embryo cells in other Asteraceae species $[15,20]$. Thus, this problem deserves future analysis to be conducted using transmission electron microscopy.

Elias et al. [20] found that Trichocline catharinensis seeds were orthodox seeds. Additionally, our anatomical and histochemical observations indicate that Carlina acaulis seeds belong to this type.

\subsection{Chemical Composition of the Cypsela}

\subsubsection{Content of Soluble Proteins, Free Amino Acids, and Total Amino Acids}

The microscopic analysis revealed the presence of protein bodies, which prompted quantification of protein and free amino acids. The $C$. acaulis cypsela was shown to contain $356.75 \pm 30.45$ and $3.38 \pm 0.03 \mathrm{~g} / \mathrm{kg}$ of soluble protein and free amino acids, respectively. Thus, the content of soluble protein in the C. acaulis cypsela is comparable to that in soybeans ( 360 to $460 \mathrm{~g} / \mathrm{kg}$ ), which is one of the richest vegetable sources of proteins [5]. The amount of proteins in the $C$. acaulis cypsela is also high in comparison with other Asteraceae plants. For example, the protein content in the Helianthus annuus L. cypsela is approx. $200 \mathrm{~g} / \mathrm{kg}$ [24], and ranges from 250 to $300 \mathrm{~g} / \mathrm{kg}$ in the cypsela of Silybum marianum (L.) Gaertner [25]. The relatively low content of free amino acids in C. acaulis cypselae is typical for plant seeds, e.g., in corn seeds, it ranges from 1 to $10 \%$ of the total pool of amino acids [26]. UPLC-FLD analysis showed the presence of eighteen amino acids, including nine essential, five conditionally essential, and four non-essential (Table 1). The total mass of the determined amino acids was $328.13 \pm 40.10 \mathrm{~g} / \mathrm{kg}$ cypselae, which corresponds to the soluble protein content.

\subsubsection{Oil Analysis}

The oil obtained by hexane extraction of ground cypselae constituted $25 \pm 2 \%$ of their weight. It was a light-yellow liquid (Figure 5B) absorbing UV-VIS radiation in the range of 190-450 nm (Figure 5A). The trace absorbance at $451 \mathrm{~nm}$ indicated the presence of small amounts of carotenoids, which was confirmed by the spectrophotometric analysis. It was shown that the content of carotenoids in the tested oil was $3.23 \mathrm{mg} / \mathrm{g}$ and the content of chlorophyll was $0.008 \mathrm{mg} / \mathrm{g}$. Absorbance at a wavelength of $275 \mathrm{~nm}$ may indicate the presence of tocopherols, especially alpha-tocopherol absorbing radiation in the range of $265-310 \mathrm{~nm}(\max 293 \mathrm{~nm})$. The lack of absorbance at 320-370 wavelengths may indicate 
the absence of polyphenolic compounds such as chlorogenic acids, apigenin, quercetin, luteolin, and kaempferol derivatives.

Table 1. Content of amino acids $(\mathrm{g} / \mathrm{kg} \pm \mathrm{SD})$ in Carlina acaulis cypsela $(\mathrm{n}=3)$.

\begin{tabular}{cccccc}
\hline \multicolumn{2}{c}{ Essential Amino Acid } & \multicolumn{2}{c}{ Conditionally Essential } & \multicolumn{2}{c}{ Non-Essential Amino Acids } \\
\hline $\begin{array}{c}\text { Compound } \\
\text { Name }\end{array}$ & Content & $\begin{array}{c}\text { Compound } \\
\text { Name }\end{array}$ & Content & $\begin{array}{c}\text { Compound } \\
\text { Name }\end{array}$ & Content \\
\hline Histidine & $9.69 \pm 1.26$ & Arginine & $37.4 \pm 4.86$ & Alanine & $14.2 \pm 1.99$ \\
Isoleucine & $9.65 \pm 1.16$ & Cystine & $7.91 \pm 1.03$ & Aspartic acid & $32.2 \pm 4.19$ \\
Leucine & $22.7 \pm 2.50$ & Glycine & $20.3 \pm 1.62$ & Glutamic acid & $79.5 \pm 10.3$ \\
Lysine & $9.30 \pm 0.84$ & Proline & $11.8 \pm 1.06$ & Serine & $15.7 \pm 2.04$ \\
Methionine & $6.18 \pm 0.87$ & Tyrosine & $9.25 \pm 1.30$ & & \\
Phenylalanine & $14.0 \pm 1.82$ & & & & \\
Threonine & $11.3 \pm 1.46$ & & & & \\
Tryptophan & $3.55 \pm 0.32$ & & & & \\
Valine & $13.5 \pm 1.48$ & & & & \\
\hline
\end{tabular}
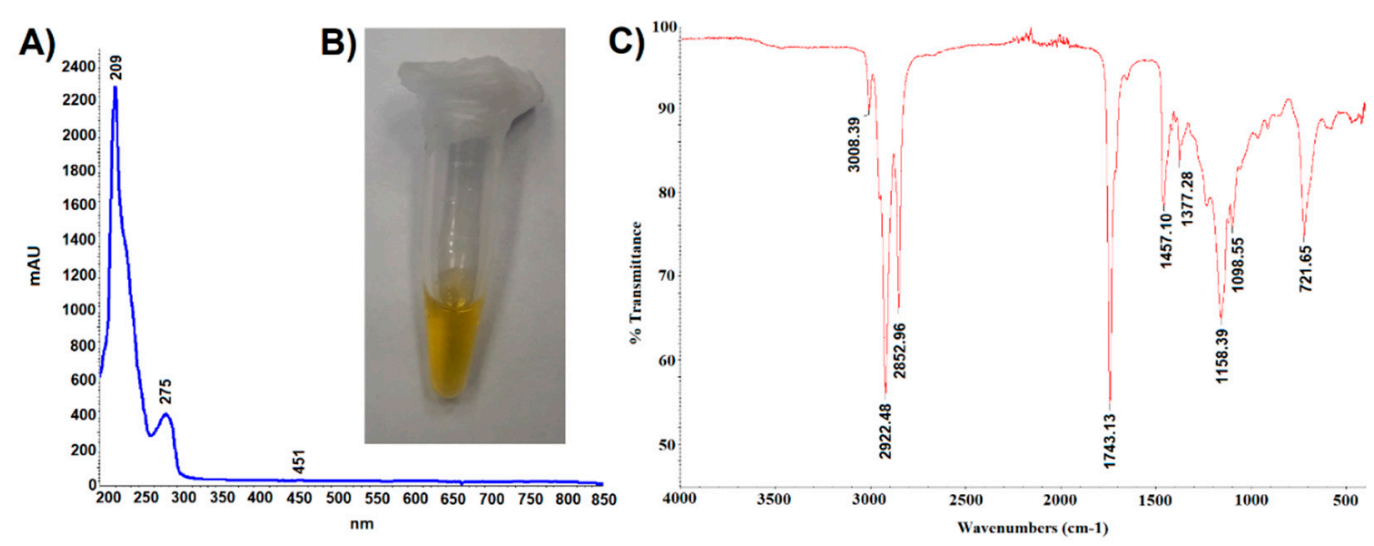

Figure 5. (A). UV-VIS spectroscopic fingerprint, (B). photography, and (C). infrared spectroscopic fingerprint of Carlina acaulis cypsela oil.

The analysis of the oil carried out with the use of attenuated ATR-IR revealed the presence of ten peaks (Figure 5C). Abdullah et al. [27] recorded the IR spectrum of linolenic acid, which showed peaks with the following wavenumber values: $3009 \mathrm{~cm}^{-1} \mathrm{C}=\mathrm{C}$ bending vibration (aliphatic), 2927, $2855 \mathrm{~cm}^{-1} \mathrm{C}-\mathrm{H}$ stretching vibration (aliphatic), $1719 \mathrm{~cm}^{-1} \mathrm{C}=\mathrm{O}$ stretching vibration (carboxylic acid), $1284 \mathrm{~cm}^{-1} \mathrm{C}-\mathrm{O}$ stretching asymmetric (carboxylic acid), $937 \mathrm{~cm}^{-1} \mathrm{C}-\mathrm{H}$ bending vibration (alkene), and $722 \mathrm{~cm}^{-1}$ group vibration (aliphatic). The presence of some of these peaks (3008, 2922, 2852, 1743, and $721 \mathrm{~cm}^{-1}$ ) in the IR spectrum of the $C$. acaulis cypsela oil may suggest the presence of structural elements common to many fatty acids. Moreover, the wavenumber peaks 2922.48 and $2852.96 \mathrm{~cm}^{-1}$ can be derived from asymmetric and symmetric stretching vibrations of $\mathrm{CH}_{2}$ and $\mathrm{CH}_{3}$. Peaks with similar wavenumber values ( 2927 and $2868 \mathrm{~cm}^{-1}$ ) were identified by Guillen and Cabo [28] in the IR spectrum of tocopherol, which may confirm the presence of tocopherols in the tested oil. However, unambiguous assignment of specific structures to all recorded signals is difficult due to the complex qualitative composition and quantitative diversity of the sample components.

\section{Fatty Acid Content}

The analysis of the oil by GC-MS showed the presence of fifteen fatty acids, including ten unsaturated acids (Table 2). An example of a chromatogram and mass spectra of analytes are presented in Figure S1 and Table S1, respectively. 
Table 2. Content of fatty acids $(\% \mathrm{~m} / \mathrm{m} \pm \mathrm{SD})$ in Carlina acaulis cypsela oil $(\mathrm{n}=3)$.

\begin{tabular}{|c|c|c|c|c|}
\hline Compound Name & FA Abbreviation & RT FAME (min) & Mass Data FAME & Content of FA \\
\hline Myristic acid & C14:0 & $11.09 \pm 0.1$ & $\begin{array}{c}242(\mathrm{M}), 211,199,185,166,157,143,129,115,97,87 \\
83,74,55\end{array}$ & $0.07 \pm 0.10 *$ \\
\hline Palmitic acid & C16:0 & $12.98 \pm 0.1$ & $\begin{array}{c}270(\mathrm{M}), 255,239,227,213,199,185,171,157,143 \\
129,115,97,87,74,69,55\end{array}$ & $7.18 \pm 0.20 *$ \\
\hline cis-5-hexadecenoic acid & C16:1 (n-11) & $13.33 \pm 0.1$ & $\begin{array}{c}283,268(\mathrm{M}), 250,236,219,194,165,152,123,110,96 \\
84,74,67,55\end{array}$ & $0.86 \pm 0.10^{\wedge}$ \\
\hline Margaric acid & C17:0 & $13.99 \pm 0.1$ & $313,284(\mathrm{M}), 253,241,199,143,101,87,74,69,55$ & $0.05 \pm 0.10^{\wedge}$ \\
\hline Stearic acid & C18:0 & $15.13 \pm 0.1$ & $\begin{array}{c}298(\mathrm{M}), 267,255,241,199,157,143,129,111,97,87 \\
74,69,55\end{array}$ & $2.92 \pm 0.05 *$ \\
\hline Unidentified compound & - & $15.49 \pm 0.2$ & $264,247,222,207,180,166,137,110,96,84,74,67,55$ & $0.16 \pm 0.10^{\wedge}$ \\
\hline 5-Octadecenoic acid & $\mathrm{C} 18: 1(n-13)$ & $15.58 \pm 0.2$ & $\begin{array}{c}296(\mathrm{M}), 278,264,247,235,222,207,194,180,166 \\
152,137,123,110,96,84,74,67,55\end{array}$ & $18.66 \pm 0.03^{\wedge}$ \\
\hline Oleic acid & $\mathrm{C} 18: 1(n-9)$ & $15.81 \pm 0.2$ & $\begin{array}{c}313,296(\mathrm{M}), 278,264,235,222,193,180,166,110,97 \\
83,69,55\end{array}$ & $4.94 \pm 0.15^{*}$ \\
\hline 8-Octadecenoic acid ${ }^{\text {a }}$ & C18:1 (n-10) & $15.92 \pm 0.2$ & $\begin{array}{c}313,296(\mathrm{M}), 264,235,222,207,180,166,138,123 \\
111,97,83,69,55\end{array}$ & $0.32 \pm 0.00^{\wedge}$ \\
\hline 9,12-Octadecadienoic acid & $\mathrm{C} 18: 2(n-6)$ & $16.34 \pm 0.2$ & $294(\mathrm{M}), 263,220,150,95,67,55$ & $0.09 \pm 0.00 *$ \\
\hline Linoleic acid & C18:2 (n-6) & $17.04 \pm 0.2$ & $\begin{array}{c}294(\mathrm{M}), 263,245,233,220,205,191,178,164,150 \\
135,123,109,95,81,67,59,55\end{array}$ & $53.2 \pm 1.07^{*}$ \\
\hline Arachidic acid & C20:0 & $17.96 \pm 0.2$ & $\begin{array}{c}326(\mathrm{M}), 295,283,269,255,241,227,199,185,171 \\
149,143,137,129,115,97,87,83,74,69,55\end{array}$ & $0.83 \pm 0.05 *$ \\
\hline alpha-Linolenic acid & $\mathrm{C} 18: 3(n-3)$ & $18.62 \pm 0.2$ & $292(M), 250,208,179,163,149,121,108,95,79,67,55$ & $0.58 \pm 0.00 *$ \\
\hline 11,14,17-Eicosadienoic acid ${ }^{b}$ & $\mathrm{C} 20: 3(n-3)$ & $18.98 \pm 0.2$ & $292,250,208,179,163,149,121,108,95,79,67,55$ & $0.12 \pm 0.00^{\wedge}$ \\
\hline Mangiferic acid & $\mathrm{C} 18: 2(n-3)$ & $19.30 \pm 0.2$ & $294(\mathrm{M}), 263,193,164,150,123,109,95,81,67,55$ & $0.09 \pm 0.00^{\wedge}$ \\
\hline
\end{tabular}


Our study showed that the content of linolenic, 5-octadecenoic, stearic, palmitic, and oleic acids in the tested oil was $53.21,18.66,2.92,7.18$, and $4.94 \%$, respectively, which is in agreement with the literature data [13]. Additionally, an unknown compound was visible in the chromatogram with a retention time of $13.3 \mathrm{~min}$, which was probably cis-5-hexadecenoic acid, as suggested by the mass of the molecular ion and literature [13]. Our research showed that $C$. acaulis oil also contained myristic, palmitoleic, margaric, 8-octadecenoic, 9,12-octadecadienoic, arachidic, alpha-linolenic, 11,14,17-eicosatrienoic, and mangiferic acids and one unidentified compound (retention time $15.49 \mathrm{~min}$ ).

The differences between our findings and Spencer's report [13] are probably the results of the use of different analytical techniques. It should be noted that Spencer et al. used gas chromatography with flame ionization detection and thin-layer chromatography in their research. Both these techniques carry a higher risk of misidentification of analytes, compared to the GC-MS used this study. Moreover, the analytical columns used in 1969 did not have such high resolution as those used today. This study therefore verifies the results of Spencer et al. and enriches the knowledge of the composition of C. acaulis cypsela oil with new data.

The high content of linoleic acid in the tested oil suggests its high pro-health value. Linoleic acid is a polyunsaturated fatty acid belonging to the omega- 6 group. It takes part in the biosynthesis of physiologically important compounds such as prostaglandins, leukotrienes, and thromboxane and is a component of lipids found in cell membranes. For this reason, supplementation thereof in the diet is necessary for the proper functioning of the human organism [29].

\section{Tocol Content}

The chromatographic analysis showed the presence of three peaks corresponding to tocopherols. An unsymmetrical peak at a retention time of approximately $7 \mathrm{~min}$ indicated coelution of gamma- + beta-tocopherol. The dominant tocopherol in the C. acaulis oil was alpha-tocopherol $(1.96 \pm 0.09 \mathrm{~g} / \mathrm{kg}$ oil $)$. The content of delta- and gamma- + beta-tocopherols was significantly lower, i.e., $6.35 \pm 0.41$, and $39.20 \pm 0.76 \mathrm{mg} / \mathrm{kg}$, respectively. The chromatographic analysis did not reveal the presence of tocotrienols. An example of a chromatogram is presented in Figure S2.

Vitamin $\mathrm{E}$ is a mixture of compounds with strong antioxidant properties that play an important role in the functioning of the human organism. These compounds must be supplied to the human organism with the diet. The main components of vitamin E are tocopherols, which protect low-density proteins and unsaturated fatty acids against oxidation [3]. The content of alpha-tocopherol in commonly produced vegetable oils has been shown to be approx. 120, 432, 173, and 260 (mg/kg) for canola, sunflower, corn, and soybean oils, respectively [30]. As a source of alpha-tocopherol, the C. acaulis cypsela oil is therefore over four-fold richer than sunflower oil and over sixteen-fold richer than canola oil.

\section{Pentacyclic Triterpenes}

As shown in literature, pentacyclic triterpenes (ursolic and oleanolic acid, lupeol, amirin and their acetate derivatives) are present in the green parts and flower heads of $C$. acaulis [11]. Since these compounds are non-polar, they should also be present in the oil fraction [31]. Although they were found in seeds of many plants species [31-33], the chromatographic analysis revealed the absence of these triterpenes in the oil from C. acaulis cypselae.

\subsubsection{Mineral Composition}

The analysis performed with the ICP-OES technique allowed determination of the profile of macro- and microelements in $C$. acaulis cypsela. The content of macronutrients $(\mathrm{g} / \mathrm{kg})$ was as follows: $\mathrm{K} 12.4 \pm 0.07, \mathrm{Mg} 5.20 \pm 0.04, \mathrm{Ca} 3.35 \pm 0.03, \mathrm{P} 12.04 \pm 0.11$, and S $7.82 \pm 0.08$. In turn, the following amounts of micronutrients (mg/kg) were detected: $\mathrm{Cu} 29.92 \pm 0.24, \mathrm{Mn} 18.19 \pm 1.03, \mathrm{Mo} 8.34 \pm 0.08$, Zn $81.04 \pm 0.32$, and Fe $109.70 \pm 2.85$. Co and Cr were not detected. Tyler and Zohlen [34] assessed the content of metals in seeds of 35 plant species growing on various types of soil. They showed 
the following ranges of the content $(\mathrm{g} / \mathrm{kg})$ of $\mathrm{K}, \mathrm{Mg}, \mathrm{Ca}$, P, and $\mathrm{S}: 8.91-8.95,2.31-2.53,7.98-9.86,4.15-7.71$, and 2.44-2.47, respectively. They also showed that the contents of such micronutrients as $\mathrm{Cu}, \mathrm{Mn}, \mathrm{Mo}$, $\mathrm{Zn}$, and Fe were in the range of 11-12, 49-77, 0.12-0.15, 35-43, and $73 \mathrm{mg} / \mathrm{kg}$, respectively. Załuski and Janeczko [35] reported that Eleuterococcus senticosus fruits contained the following amounts of macro$(\mathrm{g} / \mathrm{kg})$ and micro- (mg/kg) elements: Ca 2.49-6.88, Mg 1.43-2.81, Fe 35-53, Mn 75-364, Zn 19-41, and Cu $3-13$. Hence, it can be concluded that $C$. acaulis cypselae are a rich source of macro- and microelements, as the content of these components is on average two or three times higher than in seeds of other plants.

Some reports show that $C$. acaulis is a relatively good accumulator of metals, for example cadmium and silver [36,37]. Therefore, the content of toxic elements in cypselae was assessed. $\mathrm{Pb}$ and As were not detected; however, $\mathrm{Cd}(0.35 \pm 0.00 \mathrm{mg} / \mathrm{kg}), \mathrm{Ni}(2.51 \pm 0.025 \mathrm{mg} / \mathrm{kg})$, and $\mathrm{Al}(3.65 \pm 0.02 \mathrm{mg} / \mathrm{kg})$ were found. The contents of these metals were relatively low, which can be explained by the protective mechanism of plants preventing accumulation of heavy metals in generative organs [4].

\subsubsection{Polyphenol Content}

The chromatographic analysis showed the presence of one dominant compound with a retention time of approx. $20 \mathrm{~min}$, which was identified as chlorogenic acid. In addition, small amounts of neochlorogenic acid and trace amounts of more polar unidentified metabolites were visible in the chromatogram in the first $10 \mathrm{~min}$ of the analysis. An example of a chromatogram is presented in Figure 6. The content of neochlorogenic and chlorogenic acids was $0.22 \pm 0.02 \mathrm{~g} / \mathrm{kg}$ and $21.47 \pm 1.36 \mathrm{~g} / \mathrm{kg}$, respectively. It should be emphasized that the content of chlorogenic acid in the $C$. acaulis cypsela is very high in comparison with other plants from the Asteraceae family. For example, sunflower seeds contain about $0.73-0.97 \mathrm{~g} / \mathrm{kg}$ of this acid [38]. It is interesting that chlorogenic acid in the green parts of C. acaulis was at the level of $10 \mathrm{~g} / \mathrm{kg}$ [12], which is more than two-fold lower than in the cypsela. In turn, 3,5-di-caffeoylquinic acid determined in the green parts [12] was not detected in the cypsela.
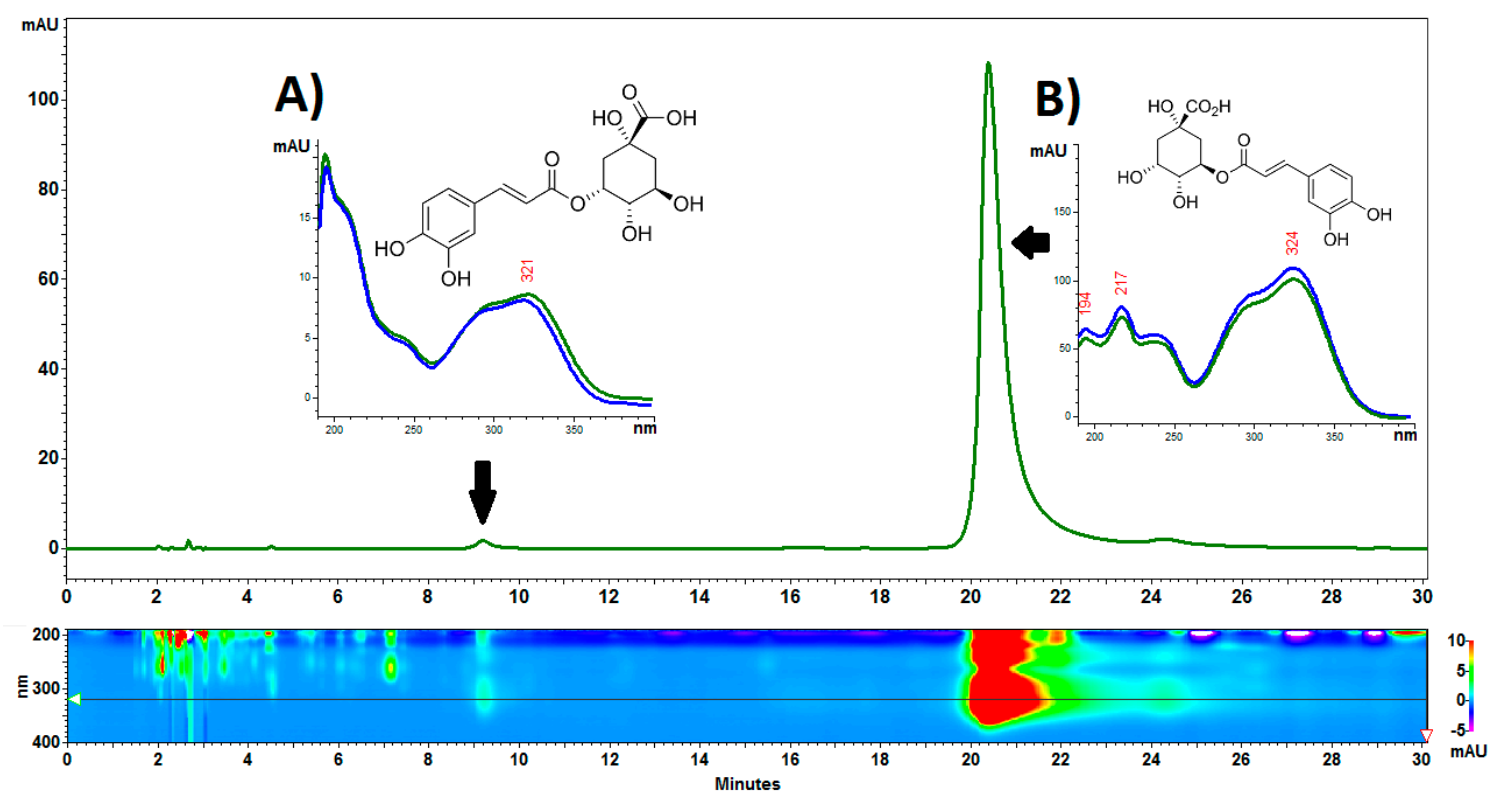

Figure 6. Example of an HPLC-DAD chromatogram of Carlina acaulis L. cypsela extract. (A). neochlorogenic acid, (B). chlorogenic acid. The analysis was performed on an RP18e LiChrospher 100 column $\left(25 \mathrm{~cm} \times 4.0 \mathrm{~mm}\right.$ i.d., $5 \mu \mathrm{m}$ particle size). The column temperature was set to $25^{\circ} \mathrm{C}$. Acetonitrile-water-trifluoroacetic acid (8:92:0.025 v/v/v) at a flow rate of $1 \mathrm{~mL} / \mathrm{min}$ was used as eluent.

Chlorogenic acid is a well-investigated compound. Its multidirectional biological activity has been described in numerous scientific reports. It has been shown to have antioxidant, anti-inflammatory, 
antilipidemic, antidiabetic, and antihypertensive effects [39-41] and, therefore, it is a desirable component of plant-derived products.

Some reports described the presence of flavonoid compounds in C. acaulis plants [10], whereas the HPTLC screening of the hydrolyzed extract did not reveal the presence of flavonoid aglycones (myricetin, quercetin, apigenin, and kaempferol). This may indicate the absence of glycoside derivatives of these flavonoids in C. acaulis cypselae.

\subsubsection{Content of Volatile Compounds}

The percentage composition of volatile compounds (VOC) detected in the C. acaulis cypselae is specified in Table 3. Examples of chromatograms and mass spectra are shown in Figure S3 and Table S2, respectively. Thirty-eight compounds belonging to different chemical classes were identified: ketones, aldehydes, esters, and heterocyclic hydrocarbons. The VOC composition in the seeds highly corresponded with their lipid content. Myristic and palmitic acid esters were contained in all the analyzed samples with relatively highest abundance in the cypselae. Monoterpenes and butanoic acid derivatives were present mainly in the ground seeds. The husk contained the lowest amounts of VOCs.

The predominant VOCs of the C. acaulis cypselae were the degradation products of higher fatty acids, obtained probably via enzymatic or oxidative hydrolysis of chemical bonds. 2- and 3-methylbutanoic acids are common compounds associated with fatty acid metabolism or lipid peroxidation. 2-Pentylfuran and hexanal are known products of linoleic acid oxidation while nonane, decane, limonene, and dodecane derive from oleic acid [42].

Monoterpenes, represented by eucalyptol, camphor, bornyl acetate, limonene, camphene, and 3-carene, were identified in C. acaulis embryo after grinding. They constituted about $15 \%$ of total VOCs, although they were not detected in the cypselae. They are probably located in the inner layer of cypsela idioblast cells and are available after crushing. Moreover, the husk constituted a barrier in the release of volatile compounds. Although terpenes are not predominant compounds in cypselae, they were reported in related species of the Asteraceae family, e.g., Cirsium setidens [43] or Heliantum annuum [24]. Interestingly, most of the monoterpenes observed in the study derive from one biosynthetic pathway, hence the low complexity of these derivatives. 
Table 3. Percentage of volatile compounds identified in Carlina acaulis cypsela ( $\% \pm S D)$.

\begin{tabular}{|c|c|c|c|c|c|c|c|}
\hline $\begin{array}{c}\text { RI } \\
\text { Calc. }\end{array}$ & $\begin{array}{l}\text { RI } \\
\text { Lit. }\end{array}$ & RT (min) & Compound & Formula & Crushed Embryo * & Husk ** & Cypsela * \\
\hline 802 & 801 & 4.33 & Hexanal & $\mathrm{C}_{6} \mathrm{H}_{12} \mathrm{O}$ & & $6.94 \pm 2.00$ & $0.64 \pm 0.12$ \\
\hline 837 & 834 & 5.32 & 3-Methylbutanoic acid & $\mathrm{C}_{5} \mathrm{H}_{10} \mathrm{O}_{2}$ & $15.85 \pm 8.26$ & & \\
\hline 841 & 841 & 5.41 & 2-Methylbutanoic acid & $\mathrm{C}_{5} \mathrm{H}_{10} \mathrm{O}_{2}$ & $0.58 \pm 0.14$ & & \\
\hline 854 & 846 & 5.55 & 2-Hexenal & $\mathrm{C}_{6} \mathrm{H}_{10} \mathrm{O}$ & & $0.09 \pm 0.07$ & $2.57 \pm 2.14$ \\
\hline 878 & 866 & 6.22 & Pentanoic acid & $\mathrm{C}_{5} \mathrm{H}_{10} \mathrm{O}_{2}$ & $0.65 \pm 2.45$ & & $0.02 \pm 0.04$ \\
\hline 895 & 901 & 6.75 & Heptanal & $\mathrm{C}_{7} \mathrm{H}_{14} \mathrm{O}$ & & $0.76 \pm 0.14$ & $0.01 \pm 0.02$ \\
\hline 930 & 929 & 7.62 & $\alpha$-Thujene & $\mathrm{C}_{10} \mathrm{H}_{16}$ & $2.59 \pm 0.76$ & $0.40 \pm 0.22$ & \\
\hline 946 & 943 & 8.03 & Camphene & $\mathrm{C}_{10} \mathrm{H}_{16}$ & $1.85 \pm 0.72$ & $0.42 \pm 0.11$ & \\
\hline 954 & 959 & 8.24 & $\gamma$-Valerolactone & $\mathrm{C}_{5} \mathrm{H}_{8} \mathrm{O}_{2}$ & $0.83 \pm 0.11$ & & \\
\hline 982 & 973 & 9.02 & Hexanoic acid & $\mathrm{C}_{6} \mathrm{H}_{12} \mathrm{O}_{2}$ & $3.16 \pm 0.77$ & $0.63 \pm 0.07$ & $2.56 \pm 0.28$ \\
\hline 991 & 993 & 9.31 & 2-Pentylfurane & $\mathrm{C}_{9} \mathrm{H}_{14} \mathrm{O}$ & $2.18 \pm 0.70$ & $0.28 \pm 0.12$ & $0.06 \pm 0.02$ \\
\hline 1003 & 1004 & 9.64 & Octanal & $\mathrm{C}_{8} \mathrm{H}_{16} \mathrm{O}$ & & $1.59 \pm 0.16$ & $0.93 \pm 0.30$ \\
\hline 1030 & 1029 & 10.38 & D-Limonene & $\mathrm{C}_{10} \mathrm{H}_{16}$ & $1.03 \pm 0.28$ & & \\
\hline 1033 & 1031 & 10.47 & Eucalyptol & $\mathrm{C}_{10} \mathrm{H}_{18} \mathrm{O}$ & $10.41 \pm 2.53$ & $1.73 \pm 0.68$ & \\
\hline 1060 & n.d. & 11.25 & 4,5-Dimethylnonane & $\mathrm{C}_{11} \mathrm{H}_{24}$ & $9.67 \pm 3.07$ & $0.35 \pm 0.12$ & $0.31 \pm 0.02$ \\
\hline 1104 & 1105 & 12.65 & Nonanal & $\mathrm{C}_{9} \mathrm{H}_{18} \mathrm{O}$ & $1.48 \pm 0.34$ & $13.94 \pm 2.06$ & $2.18 \pm 0.50$ \\
\hline 1120 & 1123 & 13.05 & 2-Ethylhexanoic acid & $\mathrm{C}_{8} \mathrm{H}_{16} \mathrm{O}_{2}$ & $2.25 \pm 1.23$ & & $0.45 \pm 0.08$ \\
\hline 1148 & 1146 & 13.83 & Camphor & $\mathrm{C}_{10} \mathrm{H}_{16} \mathrm{O}$ & $4.16 \pm 1.52$ & $1.42 \pm 0.38$ & \\
\hline 1162 & 1164 & 14.25 & 2-Nonenal & $\mathrm{C}_{9} \mathrm{H}_{16} \mathrm{O}$ & & $5.11 \pm 0.97$ & \\
\hline 1174 & 1175 & 14.60 & Octanoic acid & $\mathrm{C}_{8} \mathrm{H}_{16} \mathrm{O}_{2}$ & & $1.15 \pm 0.18$ & $1.51 \pm 0.97$ \\
\hline 1206 & 1206 & 15.58 & Decanal & $\mathrm{C}_{10} \mathrm{H}_{20} \mathrm{O}$ & $4.44 \pm 1.17$ & $15.26 \pm 2.39$ & $8.56 \pm 3.72$ \\
\hline 1271 & 1272 & 17.32 & Nonanoic acid & $\mathrm{C}_{9} \mathrm{H}_{18} \mathrm{O}_{2}$ & & & $2.09 \pm 0.59$ \\
\hline 1288 & 1285 & 17.81 & Bornyl acetate & $\mathrm{C}_{12} \mathrm{H}_{20} \mathrm{O}$ & $2.97 \pm 0.87$ & $2.79 \pm 0.82$ & \\
\hline 1294 & 1294 & 17.98 & 2-Undecanone & $\mathrm{C}_{11} \mathrm{H}_{22} \mathrm{O}$ & $1.01 \pm 0.48$ & $13.43 \pm 9.92$ & $17.09 \pm 3.29$ \\
\hline 1308 & 1308 & 18.32 & Undecanal & $\mathrm{C}_{11} \mathrm{H}_{22} \mathrm{O}$ & & $1.48 \pm 0.07$ & $0.69 \pm 0.18$ \\
\hline 1399 & 1400 & 20.33 & Tetradecane & $\mathrm{C}_{14} \mathrm{H}_{30}$ & & $0.73 \pm 0.45$ & $0.30 \pm 0.07$ \\
\hline 1409 & 1405 & 20.53 & Dodecanal & $\mathrm{C}_{12} \mathrm{H}_{24} \mathrm{O}$ & & $0.76 \pm 0.03$ & $1.01 \pm 0.23$ \\
\hline 1456 & 1455 & 21.38 & trans-Geranylacetone & $\mathrm{C}_{13} \mathrm{H}_{22} \mathrm{O}$ & $1.46 \pm 1.23$ & $2.00 \pm 0.36$ & $3.95 \pm 1.35$ \\
\hline 1468 & 1462 & 21.61 & Alloaromadendrene & $\mathrm{C}_{15} \mathrm{H}_{24}$ & $1.63 \pm 0.43$ & $3.47 \pm 0.96$ & $0.12 \pm 0.10$ \\
\hline 1514 & 1513 & 22.44 & Tridecanal & $\mathrm{C}_{14} \mathrm{H}_{22} \mathrm{O}$ & & $3.67 \pm 0.85$ & \\
\hline 1826 & 1826 & 27.08 & Isopropyl myristate & $\mathrm{C}_{17} \mathrm{H}_{34} \mathrm{O}_{2}$ & $2.50 \pm 0.30$ & $1.41 \pm 0.87$ & $30.94 \pm 1.96$ \\
\hline 1843 & n.d. & 27.30 & Farnesyl acetaldehyde & $\mathrm{C}_{17} \mathrm{H}_{28} \mathrm{O}$ & $2.12 \pm 1.20$ & $1.06 \pm 0.42$ & $3.89 \pm 1.96$ \\
\hline 1874 & n.d. & 27.69 & Phthalic acid, hept-4-yl isobutyl ester & $\mathrm{C}_{19} \mathrm{H}_{28} \mathrm{O}_{4}$ & $1.04 \pm 0.66$ & $1.01 \pm 0.50$ & $1.83 \pm 0.10$ \\
\hline
\end{tabular}


Table 3. Cont.

\begin{tabular}{|c|c|c|c|c|c|c|c|}
\hline $\begin{array}{c}\text { RI } \\
\text { Calc. }\end{array}$ & $\begin{array}{c}\text { RI } \\
\text { Lit. }\end{array}$ & RT (min) & Compound & Formula & Crushed Embryo* & Husk ** & Cypsela * \\
\hline 1898 & 1900 & 28.01 & Nonadecane & $\mathrm{C}_{19} \mathrm{H}_{40}$ & $1.64 \pm 0.28$ & $0.61 \pm 0.19$ & $2.60 \pm 0.53$ \\
\hline 1964 & n.d. & 28.77 & 2-Ethylhexyl octadecyl carbonate & $\mathrm{C}_{17} \mathrm{H}_{34} \mathrm{O}_{3}$ & $7.39 \pm 0.53$ & $3.30 \pm 0.27$ & $9.45 \pm 1.53$ \\
\hline 2024 & 2023 & 29.44 & Isopropyl palmitate & $\mathrm{C}_{19} \mathrm{H}_{38} \mathrm{O}_{2}$ & $4.49 \pm 0.38$ & $1.87 \pm 0.23$ & $5.35 \pm 0.70$ \\
\hline 2098 & 2100 & 30.21 & Heneicosane & $\mathrm{C}_{21} \mathrm{H}_{44}$ & & & $0.42 \pm 0.07$ \\
\hline 2173 & n.d. & 30.95 & 2-Ethylhexyl 4-methoxycinnamate & $\mathrm{C}_{18} \mathrm{H}_{26} \mathrm{O}_{3}$ & $0.45 \pm 0.07$ & $0.14 \pm 0.04$ & \\
\hline
\end{tabular}




\section{Materials and Methods}

\subsection{Plant Material}

Mature C. acaulis L. cypselae were obtained from the Botanical Garden of Maria Curie-Skłodowska University (UMCS) in Lublin, Poland ( $\left.51^{\circ} 16^{\prime} \mathrm{N}, 22^{\circ} 30^{\prime} \mathrm{E}\right)$. They were identified by Mykhaylo Chernetskyy and deposited in the Botanical Garden of UMCS (voucher specimen no. 2005A). They were grown in an open field. The cypselae were collected in the second half of August 2019. Once harvested, the cypselae were dried at room temperature.

\subsection{Light Microscopy}

The cypselae were placed in a humid chamber for $2 \mathrm{~h}$ and later fixed in a mixture of $2.5 \%$ glutaraldehyde with $2.5 \%$ formaldehyde in $0.05 \mathrm{M}$ cacodylate buffer (Sigma-Aldrich, Sigma-Aldrich Sp. z o.o. Poznan, Poland; pH 7.2). Next, they were washed three times in $0.1 \mathrm{M}$ sodium cacodylate buffer, dehydrated in a graded ethanol series for $15 \mathrm{~min}$ at each concentration, and kept overnight in absolute ethanol. Subsequently, the samples were infiltrated for 1 h each in 3:1, 1:1, and 1:3 (v/v) mixtures of absolute ethanol and Technovit and then stored for $12 \mathrm{~h}$ in pure Technovit. The resin was polymerized by adding a hardener. The materials were cut into $5 \mu \mathrm{m}$ thick sections using a rotary microtome, stained with $0.1 \%$ toluidine blue O, and mounted in DPX (Sigma-Aldrich, Sigma-Aldrich Sp. z o.o. Poznan, Poland). Selected Technovit sections were stained with NBB for total protein staining [44] or the PAS reaction was performed for visualization of starch and other insoluble polysaccharides [45]. Sudan Black B was used to detect the presence of lipids [46,47]. The sections were examined using a Nikon Eclipse E400 light microscope. A part of the material was fixed in a 1\% osmium tetroxide solution (in cacodylate buffer, Sigma-Aldrich, Sigma-Aldrich LLB, Poznan, Poland; pH 7.2) at room temperature for $1.5 \mathrm{~h}$. Next, this material was embedded in Technovit 7100 (Kulzer, Germany) for further histological analysis.

\subsection{Scanning Electron Microscopy}

For SEM, the cypselae were sputter-coated with gold and examined at an accelerating voltage of $20 \mathrm{kV}$ using a Hitachi S-4700 scanning electron microscope (Hitachi, Tokyo, Japan), which is housed in the Institute of Geological Sciences, Jagiellonian University in Kraków, Poland.

\subsection{Reference Standards and Chemicals}

$\delta$-tocopherol, (+)- $\gamma$-tocopherol, ( \pm )- $\alpha$-tocopherol, $D$ - $\alpha$-tocotrienol, $D$ - $\delta$-tocotrienol, $\gamma$-tocotrienol (analytical standards), methyl palmitate $(\geq 99.0 \%)$, methyl stearate $(\geq 99.5 \%)$, methyl oleate $(\geq 99.0 \%)$, methyl linoleate $(\geq 98.5 \%)$, methyl linolenate $(\geq 99.0 \%)$, betulinic $(\geq 98 \%)$, oleanolic $(\geq 97 \%)$, ursolic $(\geq 90 \%)$ acids, $\alpha$-amyrin ( $\geq 98 \%), \beta$-amyrin ( $\geq 98.5 \%)$, lupeol $(\geq 94 \%)$, chlorogenic $(\geq 95 \%)$, neochlorogenic $(\geq 98 \%)$ acids, kaempferol ( $\geq 90 \%)$, apigenin ( $\geq 97 \%)$, myricetin $(\geq 96 \%)$, quercetin ( $\geq 95 \%)$, 2-propanol $(99.9 \%)$, hexane ( $\geq 95 \%)$, gradient grade acetonitrile, methanol. and ethanol, trifluoroacetic acid ( $\geq 99 \%)$, and trimethylsulfonium hydroxide (TMSH) (0.25 M methanolic solution) were purchased from Sigma Aldrich (St. Louis, MO, USA). Lupeol acetate ( $\geq 98 \%), \alpha$-amyrin acetate $(\geq 98 \%)$, and $\beta$-amyrin acetate $(\geq 98 \%$ ) were provided by ALB Technology (ALB Materials Inc, Henderson, NV, USA). Water for HPLC was purified by ULTRAPURE Millipore Direct-Q ${ }^{\circledR}$ 3UV-R (Merck Millipore, Billerica, MA, USA). Tert-butyl methyl ether (TBME) (99.8\%) was purchased from Avantor Performance Materials Poland S.A. (Gliwice, Poland).

\subsection{Determination of the Content of Protein, Free Amino Acids, and Total Amino Acids}

The protein content was assessed using a Bradford Assay [48,49]. Free amino acids were assessed using a ninhydrin assay [50]. The profile and total content of amino acids after acidic hydrolysis 
of cypselae were examined with the UPLC-PDA technique, in accordance with the methodology published by Szkudzińska et al. [51].

\subsection{Isolation of Oil and Preparation of Samples for GC, HPLC, and HPTLC Analysis}

The cypselae were dried, pulverized and accurately weighted $(1.000 \mathrm{~g})$. Samples were extracted four times with hexane $(4 \times 30 \mathrm{~mL})$ using an ultrasonic bath $(4 \times 15 \mathrm{~min}$.) The extracts were combined and evaporated in a rotary evaporator. Accurately weighed oil (approx. $100 \mathrm{mg}$ ) was transferred into a volumetric flask $(5 \mathrm{~mL})$ and dissolved in 2-propanol. The solution was filtered through a $0.25 \mu \mathrm{m}$ polyamide membrane filter before the HPLC analysis. Accurately weighed oil (approx. $10 \pm 2 \mathrm{mg}$ ) was dissolved in $500 \mu \mathrm{L}$ TBME and derivatized by the addition of $250 \mu \mathrm{L}$ TMSH. The whole sample was shaken vigorously and the GC analysis was performed.

For the determination of phenolic compounds, after extraction with hexane, the plant material was dried and extracted with $60 \%$ ethanol $(3 \times 3 \mathrm{~mL})$ in an ultrasonic bath $(3 \times 15 \mathrm{~min})$. The extracts were combined in volumetric flasks $(10 \mathrm{~mL})$ and made up to the mark with $60 \%$ ethanol. Prior to the HPLC analysis, the extracts were filtered through $0.22 \mu \mathrm{m}$ nylon filters. Acidic hydrolysis of the extract was performed to determine the presence of flavonoid aglycones. A volume of $0.4 \mathrm{~mL}$ of $1.0 \mathrm{~mol} / \mathrm{L}$ hydrochloric acid was added to $5 \mathrm{~mL}$ of the extract and the mixture was made up to $10 \mathrm{~mL}$ with methanol in a volumetric flask. Hydrolysis was conducted for $2 \mathrm{~h}$ at $40^{\circ} \mathrm{C}$. Before the analysis, the extract was neutralized with $\mathrm{NH}_{3} \cdot \mathrm{H}_{2} \mathrm{O}$.

\subsection{Spectroscopic Analysis of Oil}

The total chlorophyll and carotenoid contents were assessed with the method proposed by Wellburn [52]. The oil (50 mg) was mixed with $1 \mathrm{~mL}$ of isopropanol, vortexed for $5 \mathrm{~min}$ at $3000 \mathrm{rpm}$, and centrifuged at $6000 \mathrm{rpm}$. Spectrophotometric measurements were carried out at 470,646, and $663 \mathrm{~nm}$ for carotene, chlorophyll b, and chlorophyll a, respectively. The DAD spectrum of the oil was recorded using a VWR Hitachi Chromaster 600 chromatograph with a 5430 Diode Array Detector and EZChrom Elite software (Merck, Darmstadt, Germany). The ATR-IR spectroscopy analysis was performed according to the procedure published previously [53].

\subsection{Fatty Acid Analysis}

The analysis was performed using an Agilent GC-MSD system (GC/MSD 6890N/5975) equipped with a HP-88 Agilent capillary column ( $60 \mathrm{~m} \times 0.25 \mathrm{~mm} ; 0.20 \mu \mathrm{m}$ film thickness), MSD ChemStation ver. E.02.02.1431 software (Agilent Technologies, Santa Clara, CA, United States), and a split-splitless injector. The oven temperature was programmed from $110^{\circ} \mathrm{C}$ to $190^{\circ} \mathrm{C}$ with $8{ }^{\circ} \mathrm{C} / \mathrm{min}$, hold for $2 \mathrm{~min}$ at $110^{\circ} \mathrm{C}$ and $13 \mathrm{~min}$ at $190^{\circ} \mathrm{C}$. The temperature of the injector was $250^{\circ} \mathrm{C}$. The injection volume was $1 \mu \mathrm{L}$ (split ratio 150:1; split flow $180 \mathrm{~mL} / \mathrm{min}$ ). Helium was used as a carrier gas at a flow rate of $1.2 \mathrm{~mL} / \mathrm{min}$. A quadrupole mass spectrometer with electron ionization (EI) at $70 \mathrm{eV}$ and with a full scan type acquisition mode $(50 \mathrm{~m} / \mathrm{z}$ to $500 \mathrm{~m} / \mathrm{z})$ was used as a detector connected with the GC. The temperature of the MS source and the MS quadrupole was set to $230^{\circ} \mathrm{C}$ and $150{ }^{\circ} \mathrm{C}$, respectively. The identification of the constituents was based on a comparison of their mass spectra with the mass spectra library NIST resources and retention times with standards. Each sample was measured in three replicates.

\subsection{HPLC and HPTLC Analysis}

The analysis was performed on a VWR Hitachi Chromaster 600 chromatograph with a 5430 Diode Array Detector, a 5440 FL Detector, and EZChrom Elite software (Merck, Darmstadt, Germany). An RP18e LiChrospher 100 column (Merck, Darmstadt, Germany) $(25 \mathrm{~cm} \times 4.0 \mathrm{~mm}$ i.d., $5 \mu \mathrm{m}$ particle size) was used for the analyses. The identity of compounds was established by comparison of retention times and PDA spectra with the corresponding standards.

Chlorogenic acids were determined using an isocratic system. The mobile phase consisted of acetonitrile-water-trifluoroacetic acid (8:92:0.025 v/v/v). The eluent flow rate was $1 \mathrm{~mL} / \mathrm{min}$. The column 
temperature was set to $25^{\circ} \mathrm{C}$. The injection volume was $1 \mu \mathrm{L}$. Data were collected between 190 and $400 \mathrm{~nm}$. The quantitative analysis was performed at $\lambda=321$ and $324 \mathrm{~nm}$ for neochlorogenic and chlorogenic acids, respectively. Each sample was measured in three replicates.

Tocopherols were determined using an isocratic system. The mobile phase consisted of acetonitrile and methanol $(5: 95 \mathrm{v} / \mathrm{v})$. The eluent flow rate was $1.2 \mathrm{~mL} / \mathrm{min}$. The column temperature was set to $30^{\circ} \mathrm{C}$. The injection volume was $5 \mu \mathrm{L}$. The quantitative analysis was performed using a fluorescence detector with an excitation wavelength at $296 \mathrm{~nm}$ and an emission wavelength at $330 \mathrm{~nm}$. Each sample was measured in three replicates.

The presence of pentacyclic triterpenes was assessed using previously published methods [11]. The presence of flavonoid aglycones was assessed by HPTLC and a previously published procedure [54].

\subsection{Determination of Minerals}

Determination of minerals was conducted according to the methodology published previously (Dresler et al., 2020). Pulverized cypselae (0.2000 g) were mineralized using $5 \mathrm{~mL}$ of the $\mathrm{HNO}_{3}: \mathrm{H}_{2} \mathrm{O}_{2}$ mixture (4:1 v/v) in DigiPREP (SCP Science, Clark Graham Baie D’Urfé, QC, Canada). The process was carried out at a temperature of $120^{\circ} \mathrm{C}$ for $2 \mathrm{~h}$. The resulting clear solutions were transferred into volumetric flasks and filled up to $25 \mathrm{~mL}$ with deionized water. The amounts of all elements were measured using ICP-OES PlasmaQuant PQ 9000 Elite (Analityk Jena AG, Jena, Germany). Effective plasma power was $1300 \mathrm{~W}$ and the plasma, auxiliary, and nebulizer argon flow rates were 14.0, 0.5, and $0.6 \mathrm{~L} / \mathrm{min}$, respectively. The attenuated radial direction of measurement for $\mathrm{Ca}, \mathrm{K}$, and $\mathrm{Mg}$ (analytical lines: 315.887, 766.491, and 285.213, respectively) and the axial direction for $\mathrm{Cd}, \mathrm{Zn}, \mathrm{Mn}, \mathrm{Fe}$, $\mathrm{Mo}, \mathrm{Cu}, \mathrm{Co}, \mathrm{Cr}, \mathrm{Ni}, \mathrm{Al}, \mathrm{Pb}$, and As (analytical lines: 214.441, 206.200, 257.610, 259.940, 202.030, 2019.227, $228.615,205.552,231.604,396.152,220.353$, and 188.970, respectively) were applied. Each sample was measured in three replicates.

\subsection{Volatile Compound Analysis}

The analyses of the $C$. acaulis cypselae were performed on a whole embryo with the husk (=cypsela), husk, and a peeled and ground embryo. Extraction was carried out using 50/30 $\mu \mathrm{m}$ DVB/CAR/PDMS SPME fiber (Supelco, Bellefonte, PA, USA). 2-undecanone (Merck, Poland) was used as an internal standard-1.0 or $0.2 \mathrm{mg} / \mathrm{mL}$ of water for the seeds and husk, respectively. A sample containing $100 \mathrm{mg}$ of cypselae and the embryo or $50 \mathrm{mg}$ of husk was placed in a $4 \mathrm{~mL}$ vial capped with an aluminum cap. Equilibration was performed at $60^{\circ} \mathrm{C}$ for $30 \mathrm{~min}$. The fiber exposition time was $15 \mathrm{~min}$, and thermal desorption was carried out for $3 \mathrm{~min}$ at $250{ }^{\circ} \mathrm{C}$ directly in the GC injection port. All analyses were performed in triplicate.

The analysis was performed using an Agilent 7890B GC coupled with the 7000GC/TQ system (Agilent Technologies, Paolo Alto, CA, USA). Separation was carried out on an HP-5 MS column; $30 \mathrm{~m}$ $\times 0.25 \mathrm{~mm} \times 0.25 \mu \mathrm{m}(\mathrm{J} \& \mathrm{~W}$, Agilent Technologies, Palo Alto, CA, USA) at a constant helium flow of $1 \mathrm{~mL} / \mathrm{min}$. The injector temperature was set at $250{ }^{\circ} \mathrm{C}$ and the sample was applied in a split mode (20:1). The temperature program was $50{ }^{\circ} \mathrm{C}$ for $1 \mathrm{~min}$, followed by $4{ }^{\circ} \mathrm{C} / \mathrm{min}$ to $130{ }^{\circ} \mathrm{C}, 10^{\circ} \mathrm{C} / \mathrm{min}$ to $280{ }^{\circ} \mathrm{C}$, and held isothermal for $2 \mathrm{~min}$. The MS source was set at $230^{\circ} \mathrm{C}$, the transfer line was $320^{\circ} \mathrm{C}$, and the quadrupole temperature was $150^{\circ} \mathrm{C}$. The electron ionization energy was set at $70 \mathrm{eV}$, scan range, $\mathrm{m} / \mathrm{z} 30-400$.

The identification was performed using MassHunter Workstation Software, Version B.08.00 coupled with the NIST17 mass spectra library, and accomplished by comparison with RI. The RI of the compounds were calculated using a series of n-alkanes (C8-C20, Merck, Poland).

\section{Conclusions}

In this study, the morphological and anatomical features as well as the chemical composition of C. acaulis cypselae were described. Our research showed that the cypselae are a rich source of nutrients such as protein (with a high proportion of essential amino acids), unsaturated fatty acids, and macro- and 
microelements; therefore, they can be a valuable supplement of the diet. The high content of tocopherols and chlorogenic acid indicates the health promoting properties of the cypselae, as the biological activity of these compounds, including strong antioxidant, anti-inflammatory, antidiabetic, antilipidemic, and antihypertensive activity, is widely described in the scientific literature. This study expands the knowledge of $C$. acaulis.

Supplementary Materials: The following are available online at http://www.mdpi.com/1422-0067/21/23/9230/s1.

Author Contributions: Conceptualization, M.S.; methodology, M.S., and B.J.P.; formal analysis, M.S., B.J.P. and M.W.; investigation, M.S., W.K., K.L., J.S. and B.M.; data curation, M.S., J.S.; writing-original draft preparation, M.S., B.J.P., W.K., M.W., B.M., D.Z., and I.S.; writing-review and editing, M.S., and M.W.; visualization, M.S., Ł.R., W.K., and B.J.P.; supervision, M.S., and M.W.; project administration, M.S.; funding acquisition, D.S., B.J.P., M.W., I.S. All authors have read and agreed to the published version of the manuscript.

Funding: This research was partially supported financially to B.J.P. and K.L. by the Ministry of Science and Higher Education of Poland as part of the statutory activities of the Department of Plant Cytology and Embryology, Institute of Botany, Faculty of Biology, Jagiellonian University in Kraków (N18/DBS/000002), Department of Analytical Chemistry, Medical University of Lublin (DS 51 and DS 52), and Department of Pharmaceutical Biology, Wroclaw Medical University (STM.DO30.17.005). The publication costs were funded by the Medical University of Lublin. The analysis of the amino acid profile was financed by the Lublin Society for the Support of Pharmaceutical Sciences. M.S. is a Scholarship holder of the Polish Minister of Science and Higher Education for Outstanding Young Scientists 2020.

Acknowledgments: This work was partially supported by the Botanical Garden UMCS in Lublin. We would like to thank cordially both Garden Director Grażyna Szymczak and Gardener Mykhaylo Chernetskyy for the access to the Carlina acaulis L. plants.

Conflicts of Interest: The authors declare no conflict of interest.

\section{References}

1. Peng, L.P.; Men, S.Q.; Liu, Z.A.; Tong, N.N.; Imran, M.; Shu, Q.Y. Fatty acid composition, phytochemistry, antioxidant activity on seed coat and kernel of paeonia ostii from main geographic production areas. Foods 2020, 9, 30. [CrossRef]

2. Lunn, J.; Theobald, H.E. The health effects of dietary unsaturated fatty acids. Nutr. Bull. 2006, 31, $178-224$. [CrossRef]

3. Böhm, V. Vitamin E. Antioxidants 2018, 7, 44. [CrossRef] [PubMed]

4. Dresler, S.; Bednarek, W.; Hawrylak-Nowak, B.; Wójcik, M. Morphometric and phytochemical profile of seeds of metallicolous and nonmetallicolous Echium vulgare populations. Biochem. Syst. Ecol. 2017, 70, 304-310. [CrossRef]

5. Wójciak-Kosior, M.; Sowa, I.; Strzemski, M. Soy as a rich source of nutrient and bioactive compounds. In Recent Progress in Medicinal Plants; Govil, J.N., Pathak, M., Eds.; Studium Press LLC: Houston, TX, USA, 2016.

6. Lele, S.S.; Naik, A. Bioactives from Plant Seeds. In Recent Progress in Medicinal Plants; Govil, J.N., Pathak, M., Eds.; Studium Press LLC: Houston, TX, USA, 2016.

7. Strzemski, M.; Wójciak-Kosior, M.; Sowa, I.; Załuski, D.; Verpoorte, R. Historical and traditional medical applications of Carlina acaulis L.-A critical ethnopharmacological review. J. Ethnopharmacol. 2019, 239. [CrossRef] [PubMed]

8. Strzemski, M.; Wojnicki, K.; Sowa, I.; Wojas-Krawczyk, K.; Krawczyk, P.; Kocjan, R.; Such, J.; Latalski, M.; Wnorowski, A.; Wójciak-Kosior, M. In vitro antiproliferative activity of extracts of Carlina acaulis subsp. caulescens and Carlina acanthifolia subsp. utzka. Front. Pharmacol. 2017, 8. [CrossRef]

9. Strzemski, M.; Wójciak-Kosior, M.; Sowa, I.; Kocjan, R.; Tyszczuk-Rotko, K. Methodological approach to determine carlina oxide-A main volatile constituent of Carlina acaulis L. essential oil. Talanta 2019, 191. [CrossRef]

10. Raynaud, J.; Rasolojaona, L. Flavonoids from leaves of Carlina acaulis. Planta Med. 1979, 37, $168-171$. [CrossRef]

11. Strzemski, M.; Wójciak-Kosior, M.; Sowa, I.; Rutkowska, E.; Szwerc, W.; Kocjan, R.; Latalski, M. Carlina species as a new source of bioactive pentacyclic triterpenes. Ind. Crops Prod. 2016, 94. [CrossRef] 
12. Strzemski, M.; Dresler, S.; Sowa, I.; Czubacka, A.; Agacka-Mołdoch, M.; Płachno, B.J.; Granica, S.; Feldo, M.; Wójciak-Kosior, M. The impact of different cultivation systems on the content of selected secondary metabolites and antioxidant activity of Carlina acaulis plant material. Molecules 2020, 25, 146. [CrossRef]

13. Spencer, G.F.; Kleiman, R.; Earle, F.R.; Wolff, I.A. Cis-5-monoenoic fatty acids of Carlina (Compositae) seed oils. Lipids 1969, 4, 99-101. [CrossRef]

14. Marzinek, J.; De-Paula, O.C.; Oliveira, D.M.T. Cypsela or achene? Refining terminology by considering anatomical and historical factors. Rev. Bras. Bot. 2008, 31, 549-553. [CrossRef]

15. Mantese, A.I.; Medan, D.; Hall, A.J. Achene structure, development and lipid accumulation in sunflower cultivars differing in oil content at maturity. Ann. Bot. 2006, 97, 999-1010. [CrossRef] [PubMed]

16. Musiał, K.; Płachno, B.J.; Światek, P.; Marciniuk, J. Anatomy of ovary and ovule in dandelions (Taraxacum, Asteraceae). Protoplasma 2013, 250, 715-722. [CrossRef]

17. Płachno, B.J.; Kurczyńska, E.; Świątek, P. Integument cell differentiation in dandelions (Taraxacum, Asteraceae, Lactuceae) with special attention paid to plasmodesmata. Protoplasma 2016, 253, 1365-1372. [CrossRef]

18. Płachno, B.J.; Świątek, P.; Kozieradzka-Kiszkurno, M.; Szeląg, Z.; Stolarczyk, P. Integument cell gelatinisation-The fate of the integumentary cells in Hieracium and Pilosella (Asteraceae). Protoplasma 2017, 254, 2287-2294. [CrossRef]

19. Jacobsen, J.V. The seed: Germination. In Embryology of Angiosperms; Johri, B.M., Ed.; Springer: Berlin/Heidelberg, Germany, 1984.

20. Elias, R.A.; Lando, A.P.; Viana, W.G.; Ortiz, J.; da Costa, C.D.; Schmidt, É.C.; Souza, L.A.; Guerra, M.P.; Steiner, N. Structural aspects of cypsela and seed development of Trichocline catharinensis (Cabrera): A Brazilian endemic species. Protoplasma 2019, 256, 1495-1506. [CrossRef]

21. Boesewinkel, F.D.; Bouman, F. The Seed: Structure. In Embryology of Angiosperms; Mohri, B.M., Ed.; Springer: Berlin/Heidelberg, Germany, 1984.

22. Baud, S.; Dubreucq, B.; Miquel, M.; Rochat, C.; Lepiniec, L. Storage reserve accumulation in Arabidopsis: Metabolic and developmental control of seed filling. Arab. B 2008, 6, e0113. [CrossRef]

23. Jimenez-Lopez, J.C.; Zienkiewicz, A.; Zienkiewicz, K.; Alché, J.D.; Rodríguez-García, M.I. Biogenesis of protein bodies during legumin accumulation in developing olive (Olea europaea L.) seed. Protoplasma 2016, 253, 517-530. [CrossRef]

24. Guo, S.; Jom, K.N.; Ge, Y. Influence of roasting condition on flavor profile of sunflower seeds: A flavoromics approach. Sci. Rep. 2019, 9. [CrossRef]

25. Kohlmünzer, S. Farmakognozja; PZWL: Warsaw, Poland, 2007; pp. 1-670.

26. Amir, R.; Galili, G.; Cohen, H. The metabolic roles of free amino acids during seed development. Plant Sci. 2018, 275, 11-18. [CrossRef] [PubMed]

27. Abdullah, B.M.; Salih, N.; Salimon, J. Optimization of the chemoenzymatic mono-epoxidation of linoleic acid using D-optimal design. J. Saudi Chem. Soc. 2014, 18, 276-287. [CrossRef]

28. Guillén, M.D.; Cabo, N. Infrared spectroscopy in the study of edible oils and fats. J. Sci. Food Agric. 1997, 75, 1-11. [CrossRef]

29. Whelan, J.; Fritsche, K. Linoleic acid. Adv. Nutr. 2013, 4, 311-312. [CrossRef]

30. Grilo, E.C.; Costa, P.N.; Gurgel, C.S.S.; Beserra, A.F.L.; Almeida, F.N.S.; Dimenstein, R. Alpha-tocopherol and gamma-tocopherol concentration in vegetable oils. Food Sci. Technol. 2014, 34, 379-385. [CrossRef]

31. Madrigal, R.V.; Plattner, R.D.; Smith, C.R. Carduus nigrescens seed oil-A rich source of pentacyclic triterpenoids. Lipids 1975, 10, 208-213. [CrossRef]

32. Jäger, S.; Trojan, H.; Kopp, T.; Laszczyk, M.N.; Scheffler, A. Pentacyclic triterpene distribution in various plants-Rich sources for a new group of multi-potent plant extracts. Molecules 2009, 14, 2016-2031. [CrossRef]

33. Ahmed, D.; Khan, M.I.; Sharma, M.; Khan, M.F. Novel pentacyclic triterpene isolated from seeds of Euryale ferox Salisb. ameliorates diabetes in streptozotocin induced diabetic rats. Interdiscip. Toxicol. 2019, 11, $275-288$. [CrossRef]

34. Tyler, G.; Zohlen, A. Plant seeds as mineral nutrient resource for seedlings-A comparison of plants from calcareous and silicate soils. Ann. Bot. 1998, 81, 455-459. [CrossRef]

35. Załuski, D.; Janeczko, Z. Variation in phytochemicals and bioactivity of the fruits of Eleutherococcus species cultivated in Poland. Nat. Prod. Res. 2015, 29, 2207-2211. [CrossRef] 
36. Dresler, S.; Strzemski, M.; Kováčik, J.; Sawicki, J.; Staniak, M.; Wójciak, M.; Sowa, I.; Hawrylak-Nowak, B. Tolerance of facultative metallophyte Carlina acaulis to cadmium relies on chelating and antioxidative metabolites. Int. J. Mol. Sci. Artic. 2020, 21, 2828. [CrossRef] [PubMed]

37. Dresler, S.; Hawrylak-Nowak, B.; Strzemski, M.; Wójciak-Kosior, M.; Sowa, I.; Hanaka, A.; Gołoś, I.; Skalska-Kamińska, A.; Cieślak, M.; Kováčik, J. Metabolic changes induced by silver ions in Carlina acaulis. Plants 2019, 8, 517. [CrossRef] [PubMed]

38. Pedrosa, M.M.; Muzquiz, M.; García-Vallejo, C.; Burbano, C.; Cuadrado, C.; Ayet, G.; Robredo, L.M. Determination of caffeic and chlorogenic acids and their derivatives in different sunflower seeds. J. Sci. Food Agric. 2000, 80, 459-464. [CrossRef]

39. Liang, N.; Kitts, D.D. Role of chlorogenic acids in controlling oxidative and inflammatory stress conditions. Nutrients 2015, 8, 16. [CrossRef] [PubMed]

40. Xu, J.G.; Hu, Q.P.; Liu, Y. Antioxidant and DNA-protective activities of chlorogenic acid isomers. J. Agric. Food Chem. 2012, 60, 11625-11630. [CrossRef] [PubMed]

41. Santana-Gálvez, J.; Cisneros-Zevallos, L.; Jacobo-Velázquez, D.A. Chlorogenic Acid: Recent advances on its dual role as a food additive and a nutraceutical against metabolic syndrome. Molecules 2017, 22, 358. [CrossRef]

42. Li, P.L.; Zhu, Y.; Li, S.H.; Zhang, A.X.; Zhao, W.; Zhang, J.L.; Chen, Q.C.; Ren, S.F.; Liu, J.K.; Wang, H.J. Variation patterns of the volatiles during germination of the foxtail millet (setaria italic): The relationship between the volatiles and fatty acids in model experiments. Molecules 2020, 25, 1238. [CrossRef]

43. Kim, S.J.; Lee, J.Y.; Choi, Y.S.; Sung, J.M.; Jang, H.W. Comparison of different types of SPME arrow sorbents to analyze volatile compounds in cirsium setidens nakai. Foods 2020, 9, 785. [CrossRef]

44. Fisher, D.B. Protein staining of ribboned epon sections for light microscopy. Histochemie 1968, 16, 92-96. [CrossRef]

45. Wędzony, M. Fluorescence Microscopy for Botanists; Department of Plant Physiology Monographs 5: Kraków, Poland, 1996; pp. 1-128.

46. Johansen, D.A. Plant Microtechnique; McGraw-Hill Book Co.: New York, NY, USA, 1940; pp. 1-530.

47. Paterson, R.A. Botanical Histochemistry. Principles and practices. Science 1963, 140, 634-635. [CrossRef]

48. Bradford, M.M. A rapid and sensitive method for the quantitation of microgram quantities of protein utilizing the principle of protein-dye binding. Anal. Biochem. 1976, 72, 248-254. [CrossRef]

49. Sapan, C.V.; Lundblad, R.L. Review of methods for determination of total protein and peptide concentration in biological samples. Proteom. Clin. Appl. 2015, 9, 268-276. [CrossRef] [PubMed]

50. Moore, S.; Stein, W.H. A modified ninhydrin reagent for the photometric determination of amino acids and related compounds. J. Biol. Chem. 1954, 211, 907-913. [PubMed]

51. Szkudzińska, K.; Smutniak, I.; Rubaj, J.; Korol, W.; Bielecka, G. Method validation for determination of amino acids in feed by UPLC. Accredit. Qual. Assur. 2017, 22, 247-252. [CrossRef]

52. Wellburn, A.R. The spectral determination of chlorophylls a and $b$, as well as total carotenoids, using various solvents with spectrophotometers of different resolution. J. Plant Physiol. 1994. [CrossRef]

53. Strzemski, M.; Wójciak-Kosior, M.; Sowa, I.; Agacka-Mołdoch, M.; Draczkowski, P.; Matosiuk, D.; Kurach, Ł.; Kocjan, R.; Dresler, S. Application of Raman spectroscopy for direct analysis of Carlina acanthifolia subsp. utzka root essential oil. Talanta 2017, 174, 633-637. [CrossRef]

54. Sowa, I.; Wójciak-Kosior, M.; Strzemski, M.; Rokicka, K.; Blicharski, T.; Kocjan, R. Analysis of compounds with phytoestrogenic activity in dietary supplements with use of HPTLC-densitometry method. Acta Pol. Pharm. Drug Res. 2014, 71, 265-269.

Publisher's Note: MDPI stays neutral with regard to jurisdictional claims in published maps and institutional affiliations.

(C) 2020 by the authors. Licensee MDPI, Basel, Switzerland. This article is an open access article distributed under the terms and conditions of the Creative Commons Attribution (CC BY) license (http://creativecommons.org/licenses/by/4.0/). 